associated physical properties. The molecular chain structure is particularly emphasized and is illustrated by large-scale molecular models. Then, with the aid of mechanical analogies, the packing of the chains is related to the physical properties, tight-, mediumand loose-packing corresponding to fibres, heatsoftening plastics and rubbers respectively. In the case of the rubber structures, the chains can be locked by means of cross-connecting atoms, and this produces a heat- and chemical-resistant material which is called a heat-hardening or thermosetting plastic. The use of fillers to improve this plastic is also discussed. To illustrate the chemistry, the phenolformaldehyde plastic is considered. The last part of the film ranges over the industrial use of plastics. The production of the film is of a high standard, and scientific accuracy has been maintained throughout. No doubt the film will be widely used for educational purposes, and it can be strongly recommended for showing to senior forms of schools, etc. Applica. tions for the loan of prints should be made to Bakelite, Ltd., 18 Grosvenor Gardens, London, S.W.1.3.

\section{Plant Propagation by Cuttings}

A USEFUL short paper by E. E. Kemp ( $J$. Roy. Hort. Soc., 73, Payf 9, 291-305; Sept. 1948) gives some very pragifyal information on the rooting of more odiffipa attings. The author draws on the extensiy practical experience of the Edinburgh Rod Botanic Garden to describe the important fadtor of selection of material for this type of propagation. Descriptions of this are greatly helped by a series of very clear photographs. In the sections on preparation of cuttings for insertion and on rooting media, the writer interprets practically the physio. logical approach typified by Priestley and Swingle. Nodal cuttings are more generally satisfactory because of the absence of pith and the presence of additional meristem. The effect of environment on the healing of the cut wound and subsequent formation of callus and roots are also described on a physiological basis, which further indicates the chief desiderata of the rooting medium-air and water. It is indeed refreshing, in this era of hormonal rooting of cuttings, to find a good exposition of the blending of 'normal' physiology with practice for dealing with some of the difficulties of propagation.

\section{Industitial Management}

A BоokLeт by Colonel L. Urwick entitled, "Occasional Papero No. 1: A Short Survey of Industrial -Mfloggement", is the first of a series published Whe British Institute of Management; it corbsists 32 pages and is priced at $2 s$. 6d. After refiewing successively the nature of management, the evolution of 'scientific management', and the mechanics and dynamics of management, Colonel Urwick emphasizes the immense amount of work still to be done, alike in widening and deepening the field of research and in securing a uniform application of the results already attained. This admirably written paper displays to the full the wide range of the author's thought and reading and his keen appreciation of the work of F. W. Taylor, Mary P. Follett and Elton Mayo. Merely as an introduction to the literature of management it could scarcely be bettered, and the bibliographical references are full and properly placed; but beyond this, Colonel Urwick writes much that is pertinent on such matters as the control of production, the selection of personnel, joint consultation, job analysis and the like. This paper sets a high standard which succeeding papers will do well if they can maintain.

\section{Engineering Metrology}

A FULL-TINE postgraduate course in engineering metrology (technical measurement), extending over one academic year, is being started this year as a permanent feature in the courses provided at the Manchester Municipal College of Technology. The course will deal with the science and practice of measurement in relation to engineering products and the machine tools employed in production, and to industrial and scientific research. In addition to the subject of metrology, other aspects of engineering will be dealt with in the course, and facilities for research will be provided. This course, which is the first of its kind in Great Britain, represents an initial step towards solving the problems whereby the accumulated store of engineering knowledge can be passed on to the newcomers in the engineering industries and professions. Candidates for admission to the course must be of postgraduate standing. In the first year the number of admissions will be limited to a maximum of about twelve. Further information may be obtained from the Principal, College of Technology, Manchester, 1.

\section{Biology of Water Supply}

THE exhibit at $\rho^{\text {the }}$ British Museum (Natural History) show how living organisms affect our water suphes has recently been extended and rearrondeld. To help the public to a better understarding of the display the original pamphlet called the "Biology of Water Supply" has been re-written by Dr. Anna Hastings and may be obtained from the Museum. Besides descriptions of the plants and animals which may enter waterworks, the pamphlet also contains an account of the treatment of river waters, the standard tests for purity, how water is delivered to the consumer and how cast-iron mains are corroded, as well as a classified list of all the plants and animals which affect water supply in some way. The pamphlet would be of considerable help to sixth-form biology teachers making use of project riethods.

\section{Research Boards of the Department of Scientific and Industrial Research}

THE following new members of the Research Boards of the Department of Scientific and Industrial Research have been announced. Building Research Board : C. W. D. Rowe, managing director, London Brick Co. (a former member of the Board); B. Sandercock, member of executive council, Amalgamated Society of Woodworkers; R. M. Wynne Edwards, Messrs. Richard Costain, Ltd. (formerly director of constructional plant, Ministry of Works). Chemistry Research Board : Prof. M. G. Evans, professor of physical chemistry, University of Manchester; Dr. H. W. T. Thompson, lecturer in chemistry, University of Oxford; Dr. F. Roffey, Distillers Co., Ltd. Forest Products Research Board: Col. A. H. Lloyd, Imperial Forestry Institute, Oxford; H. J. Nuttall, director, Thomas White and Son, Ltd. ; V. A. M. Robertson, chief civil engineer, Southern Region, British Railways. Fuel Research Board : Dr. R. Holroyd, research manager, Billing. ham Division, Imperial Chemical Industries, Ltd. ; Sir Charles Ellis, scientific member of the National 
Coal Board; Sir Cyril Hinshelwood, professor of chemistry, University of Oxford. Mechanical Engineering Research Board: Dr. C. Dannatt, chief electrical engineer and director, Metropolitan-Vickers Electrical Co.; Pest Infestation Research Board : Dr. C. B. Williams, chief entomologist, Rothamsted Experimental Station.

\section{New Trends in Biblogy Teaching}

"New Trends in Biology Teaching" is the theme of a Conference which is being held during May 6-7 at the Bgrough Polytechnic, London, S.E.1. This Conference is sponsored by the Association of Assistant Mistresses, the Association of Women Science Teachers, the British Social Hygiene Council, the Joint Committee of the Four Secondary Associations, the Ling Physical Education Association, the National Union of Teachers, the Royal College of Midwives, the Royal College of Nursing, the Science Masters' Association and the School Nature Study Union. Prof. S. Mangham, of University College, Southampton, will give an opening address on "Biology for Tomorrow". He will be followed by Miss Hilda Franks on "Syllabuses". Dr. L. M. J. Kramer is giving a lecture demonstration, "Preparing and Presenting Inexpensively a Year's Course Based on the Theme, 'The Child's Microbial Heritage'". At the final session Mr. Richard Palmer will talk on "Some Neglected Aspects of Human Biology in Schools". Tickets for the Conference can be obtained from the British Social Hygiene Council, Tavistock House North, London, W.C.1, price $5 s$.

\section{South-Eastern Union of Scientific Societies}

THe fifty-third annual congress of the SouthEastern Union of Scientific Societies will be held at King's School, Canterbury, during April 19-23. The new president of the Union, Mr. F. H. Edwards, of the Geological Survey, will give an address on "Geological Surveys and their Influence". A full programme of lectures, visits and excursions has been arranged, and approximately one day has been allotted to each of the three sections of archæology, geology and zoology. These sections will meet on April 20, 21 and 22 under their presidents, Mr. S. S. Frere, Mir. A. Wrigley and Major Maxwell Knight, respectively. A special feature of the congress is the 'Young Naturalists' Evening' on April 22, when a team of experts will answer questions from young naturalists. The honorary general secretary of the Union is Mr. H. Lambert, of 68 Grosvenor Avenue, Carshalton, Surrey, and the honorary local secretary for Canterbury is Mr. David Stainer, of Salisbury House, St. Thomas's Hill, Canterbury.

\section{Colonial Servige : Recent Appointments}

THE following appointments in the Colonial Service have been announced: P. S. Castle, agricultural officer. Gold Coast ; D. Jardine, geologist, Nigeria, seconded to the Falkland Islands; I. H. Gordon, pathologist, Nigeria; G. F. P. Doran, veterinary officer, Tanganyika; C. Douglas, veterinary officer, Gambia ; Mïss B. A. Bennett, meteorological assistant, Bermuda; F. H. Bridge, development officer, Veterinary Department, Nigeria; J. E. McK. Horne, assistant conservator of forests, Nigeria; W. MacDonald, agricultural officer, Nyasaland; H. A. Osmaston, assistant conservator of forests, Uganda; W. J. A. Payne, animal husbandry officer, Fiji ; G. Williamson, temporary veterinary education officer, Nigeria; J. V. Lewis (administrative officer,
Tanganyika), deputy director of agriculture (marketing), Nyasaland; T. Bell (senior agricultural officer, Palestine), senior agricultural officer, Kenya; A. Jeffries (chief fruit inspector, Department of Agriculture and Fisheries, Palestine), agricultural officer, Tanganyika; L. A. de S. Powell (assistant headmaster, School of Agriculture, Jamaica), agricultural officer (Grade 1), Jamaica ; C. S. Cree (assistant conservator of forests, Uganda), senior assistant conservator of forests, Northern Rhodesia; J. Evans (assistant conservator of forests, Palestine), assistant conservator of forests, Nigeria; K. V. W. Nicholls (meteorological officer, Federation of Malaya), meteorologist, East African High Commission.

\section{Announcements}

THE Ministry of Agriculture and Fisheries announces the following appointments: Mr. W. Morley Davies, provincial director for the East Midland Province of the Nathonal Agricultural Advisory Service, to be senior education and advisory officer to succeed Dr. W. K. Slater, who, as already announced, has been appointed secretary to the Agricultural Research Council in succession to the late Sir John Fryer; Mr. Arthur Jones, director in Wales, National Agricultural Advisory Service, to be provincial director for the East Midland Province ; and Mr. D. Walters-Davies, deputy provincial director, to be director in Wales.

THE Chemical Society invites applications for grants foy research in all branches of chemistry. Application forms should be submitted not later than May 10. Full particulars can be obtained from the Goneral Secretary, Chemical Society, Burlington House, Piccadilly, London, W.1.

A MEETING of the council of directors of the International Yrion against Cancer will take place in Paris during July 18-22. Also participating will be govenment delegates of the Union, delegates of non-government organisations which are members of the Union, and members of the International Cancer Research Commission, which is integrated in the Union. Further information can be obtained from the Union Internationale contre le Cancer, 6 Avenue Marceau, Paris, $8^{\mathrm{e}}$.

$\mathrm{ON}_{\mathrm{N}}$ the ocgetsion of the Conference of the International Unon of Chemistry during September 6-20, a colloguium on macromolecules will be held at Amsterdam during September 2-5. The main sub. ject will be polymerization kinetics, and macromolecules in solution will also be discussed. Full details may be obtained from the organising committee at P.O. box 71, Leyden, Netherlands.

The Manghrester Municipal College of Technology of the University of Manchester offers to part-time studento six scholarships and six exhibitions varying in value up to a maximum of $£ 140$ plus approved fees, teyable for three years in any one of the full-time day courses of the College. Forms of application may be obtained from the Registrar of the College of Technology, Manchester, 1, and must be completed before June 20.

Tue Physidal Society announces that it has caught up arrears of publication and is able to promise much more speedy publication for papers both in its Section A (atomic and sub-atomic physics) and its Section B (macroscopic physics). 